\title{
African Pentecostal spirituality as a mystical tradition: How regaining its roots could benefit Pentecostals
}

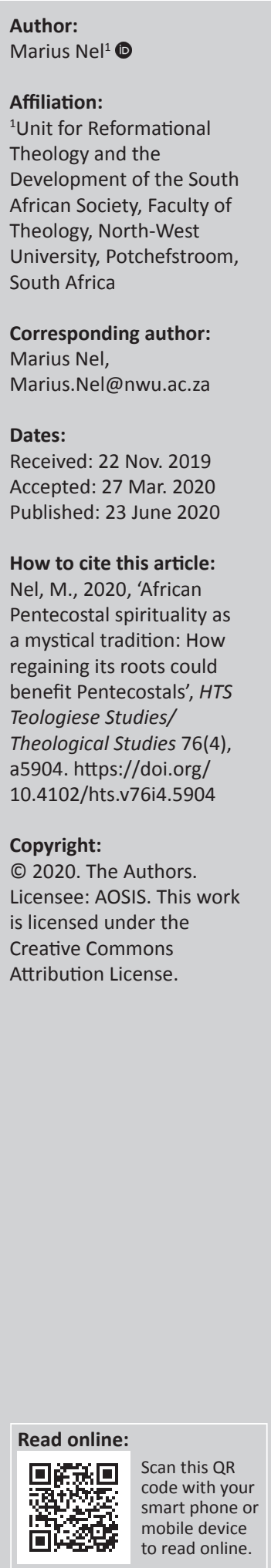

Western academic theology do not succeed in accounting for the identity and faith culture of African Pentecostals for at least two reasons. In the first place, because as part of the Pentecostal movement it grew from the holiness, divine healing and revivalist movement that went back to Pietism and emphasised a holistic effective spirituality, and secondly, because it links with the holistic tradition of African traditional religions and worldview that share some aspects of the Old Testament realist way of thinking. African Pentecostalism needs another language to describe its unique way of doing theology in direct conjunction with spirituality. It is argued that the language of the time-honoured practice of mysticism is suitable for explaining its spirituality. Theology and spirituality should mutually inform and constitute each other, as emphasised in mystical theology, for Pentecostal theology to be a valid reflection and meditation on the experience of consciousness of the involvement of God. African Pentecostals will benefit by learning from this ancient tradition by using concepts of mystical theology to find words to state the unsayable. The article closes by asking what the language of mysticism would entail for Pentecostals. Several aspects that define Pentecostal spirituality demonstrate their relation with mystical theology, such as a separate experience of sanctification, an acknowledgement of affections in expressing religious sentiments, a different way of interpreting and participating in reality, ecstatic speech and a continual emphasis on a personal, experiential encounter with the Spirit of God.

Keywords: Pentecostalism; African Pentecostalism; mystical theology; encounter; spirituality.

\section{Introduction}

Is Pentecostalism a Protestant tradition? In particular, is the Pentecostal movement that started at the beginning of the 20th century in the USA and various other parts of the world a part of evangelicalism, as many scholars assert, that Pentecostal theology is evangelical theology plus tongues? Pentecostalism is characterised by some features that one could loosely label Protestant, and more specifically, evangelical, such as the emphasis on the Bible as the authority for defining the teaching and practice of Christian life and the expressed emphasis that each Christian needs a conversion experience and should testify to their salvation to the 'unsaved'. However, just as Pentecostalism's continuationist sentiment that determines its hermeneutic betrays that despite superficial similarities there is a significant divide between Pentecostalism and Protestant evangelicalism. Western academic theology that involves rational systematic analyses of the 'content of faith', that is the nature, purposes and activity of God in relation to the world (Asamoah-Gyadu 2005:7), is not suitable to describe Pentecostal spirituality and theology. ${ }^{1}$ It represents a 'religion of the heart' as opposed to Protestants' predominant 'religion of the intellect' (Cox 1995:209). Although evangelicalism cites the Bible as its sole source of authority, its logo-centric parameters significantly failed to account for the mystery-laden qualities of a human life in encountering the 'mystery' (Castelo 2017:84).

Their epistemolological paradigm secures truth typically rationally, leaving little room for mystical sensibilities. It might be true to state that Pentecostalism is best not to be understood theologically, as 'theology' is defined by how Protestants think about it, as an intellectual principle or set of principles that shape beliefs and practices. It is the best rather to think of Pentecostalism as a set of practices characterised by its grass roots, top-down diversity that contain within them a plethora of theological meanings that cannot be categorised in the manner of a common

1.Pentecostal spirituality could be defined as people's awareness and lived experience with God (see Anderson 2016:315) and the integration of beliefs and practices in the affections which are themselves evoked and expressed by those beliefs and practices (Land 1993:1). It is best expressed in the actions of Pentecostal people at worship and prayer. 
Protestant myth of a lone conscientious theological person of European descent (Payne 2018:541-542).

It has been argued that Pentecostals have more in common with Christian mysticism, such as the same experiential impulse, and emphasis on the affective and language, a thesis that is investigated further in this article. It is submitted that the same is true (and especially so) of African Pentecostal spirituality that is characterised by rousing sermons, call and response, fervent prayer, soul-stirring music, shouting, dancing and passionate testimony that engage persons also on the level of their emotions, helping them to encounter God in a way that affects all aspects of a believer's life, including the intellect (Harris 2016:248). The global South speaks of God in intimate terms, expecting God's direct intervention in the believers' and churches' affairs on a daily basis. The Christianity that missionaries exported to Africa was a too cerebral white man's religion, a classroom religion in contrast to African religions that were essentially 'spiritual' religions (Taylor 1963:21-22). African Pentecostals live with a worldview where demons and their leader co-determine what happens on earth. In African Pentecostalism, forefathers are honoured but their potential of relapse into the dark world of evil spirits and demons is viewed as a significant part of reality (Keener 2016:88-92). ${ }^{2}$ The global north may use their theological categories to deem the beliefs of the global south as naïve and simplistic. What should be kept in mind, however, is that the future of Christianity on the planet probably has moved to the majority world.

An argument heard in the greater decolonialism debate is that Western theological categories are not useful to describe and explain African Pentecostalism. ${ }^{3}$ Africa uses narratives in signifying the significant elements in their spirituality that is demonstrated by Castelo (2017:20) by the words of Athanasius when he writes about comprehending the theological neologism of homoousious: 'verbum non est, sed res ubique', implying that 'although the word is not here or readily understandable, the reality is everywhere'. A precondition for African Pentecostal spirituality is that it should be based on regular encounters between God and human beings, called the heartbeat of their faith by Asamoah-Gyadu (2005:7) and resulting in their spirituality being embodied and combining emotion, will power and rational elements in a holistic way. In the Pentecostal world, it is seen as impossible to do or understand theology, including theology of spirituality, without conforming to the requirement of personally meeting and knowing God in a unique sense. The anti-intellectualist urge within the movement is related to their observation that academic theology could be

2.In the article, the scope is limited to African Pentecostalism, implying indigenous and independent churches that originated apart from and partly as a reaction to missionary Christianity. It includes the African Spirit churches as an integral part of African initiated churches in sub-Saharan Africa.

3.Whilst classical Pentecostal churches established in Africa subscribe to the doctrines and practices prevalent in the worldwide Pentecostal movement, Pentecostal churches that developed independently in Africa (Omenyo 2014:133) call themselves independent neo-Pentecostal/charismatic churches. They enrich their practices by reclaiming powerful features of African religious and mystical motifs (Cox 1995:206), such as a deepened awareness regarding Satan as well as demons and evil, viewing life as a power encounter and a spiritual battle, requiring certain and evil, viewing life as a power encounter and a spiritual battle, requiring certain
rituals or covenants to consolidate relationships with saints, angels, Jesus and the rituals or covenants to consoli
Spirit (Omenyo 2014:145). endeavoured without even believing in and serving God, something that is unimaginable for them. ${ }^{4}$

\section{African Pentecostalism, the Pentecostal movement and African traditional religion}

Shortly after the Azusa Street Revival started in 1906 in Los Angeles, missionaries visited South Africa and established what would become classical Pentecostal denominations. In most cases, these denominations maintained contact with the American mother movement that has kept on influencing the Pentecostal churches in Africa until today. However, in time Pentecostalism expanded and was indigenised by Africans as part of the continent-wide movement associated with the African Indigenous/Independent Churches (AIC), and not causally linked to the origins of North American Pentecostalism (Asamoah-Gyadu 2005:1-2). The gospel was reinterpreted, indigenised, inculturated and contextualised in terms of the African worldview of mystical causalities and African traditional religion (ATR) (Quayesi-Amakye 2016:287), ${ }^{5}$ although African Pentecostalism rejected indigenous African religions as harbingers of demons and evil spirits, as most AICs also do (Omenyo 2014:138). ${ }^{6}$ By including and transforming certain elements of pre-existing religions which still retain a strong grip on cultural subconscious, and confronting the spiritual world, Pentecostalism has become the fastest growing religion in Africa (Anderson 2016:312). Vernacularising does not necessarily mean syncretising Christianity; Christ ceased to be an alien and stranger to Africans and rather becomes their host in their cultural context (Quayesi-Amakye 2016:289). This led to an alternative version of Pentecostalism that assimilated a wide variety of African indigenous religious practices and African Pentecostals separated themselves in this sense from the traditional classical Pentecostal denominations. Their effectiveness in reaching Africans successfully was linked with some of the elements that the ATRs traditionally emphasised, in particular the dualistic view of the universe consisting of a visible part that portrays and reflects what happens in the invisible part, where good and evil powers constantly oppose each other. At the same time, ATRs ministered to the person in holistic terms because it did not divide the human being into different parts, as was the custom in Western science that investigated and

4.The distinction between theology and spirituality is the product of enlightenment positivist and modernist thought forms in the same manner as male-female, positivist and modernist thoughtforms in the same manner as male-female, public-private, society-individual, secular-sacred and rational-irrational/non rational (Payne 2018:545). In the west, theology dominated in terms of academy and spirituality in terms of the church, with spirituality increasingly being privatised (Castelo 2018:556). In the practice of Pentecostalism, spirituality and theology rather serve in terms of an interface where one cannot truly be itself without the other.

5.It is a valid question whether it is possible to generalise when one speaks about African worldview and traditional religions. Although ample room should be left for diversity within Africa, it is also true that there is a certain unity of thought which appears to pervade Africa in a way that is quite unlike anything perceived in Europe Asia or the Americas. This makes it possible and viable to speak of 'African traditional Asia or the Americas. This makes it possible and viable to speak of 'African traditional parts of Africa (Anderson 1991:11).

6.Pentecostals do not accept all the aspects of African contextualisation and find many of their practices and theology syncretistic and unacceptable, such as many of their practices and theology syncretistic and unacceptable, such as
shamanism and divination (Anderson 2016:312). They do not regard themselves as of the same spiritual fold as the AICs (Quayesi-Amakye 2016:299). 
systematised things or experiences by means of dispassionate analytical probing (Dierks 1983:52). Another element that was essential to ATRs, spirit possession, was also domesticated and subordinated to the Pentecostal practice of Spirit baptism. By emphasising the power of the Holy Spirit, it provides in the needs of contemporary believers, including personal, social and national catastrophes (Nel 2018:142). The natural world was viewed as a religious universe, imbued with meaning; there were various objects and events that conveyed these religious meanings. Certain persons were skilled in identifying religious objects and discerning God's word and would be conveyed to them as an indication that God was active and participating in nature and human life (Ware 2005:12). African Pentecostalism also provided in the direct needs of ordinary people and in the idiom that they understand. Traditional Pentecostal values such as Spirit baptism, charismatic worship and an emphasis on the experiential in spirituality remained as defining factors in African Pentecostalism. New emphases fed by indigenisation contributed to popularise the movement to such an extent that researchers have predicted that Pentecostalism would overtake Roman Catholicism as Africa's largest Christian tradition within a decade (Johnson, Barrett \& Crossing 2010:36).

At the moment, parts of Africa debate the issue of indigenised knowledge and the need for the development of curricula reflecting an Africanised epistemology at all levels of education because of what they view as the inadequacy of an epistemology in Africa that was established by colonial forces and supported by a Western worldview. It is suggested that African Pentecostalism has not felt much need to indigenise or Africanise its theology because it is already decolonised and indigenised since its inception in Africa by using an African worldview and relating to certain aspects of ATR, the two aspects that are critical in formulating a decolonised African epistemology.

\section{African Pentecostal spirituality in terms of colonial categories of rational explanation of the Aufklärung [Enlightenment]}

Traditional African culture has never passed through the rationalistic critique of the Enlightenment that resulted in the modern Western worldview, with its mechanistic and closed view of the universe. In Africa, the spiritual world was a central concept in all religious beliefs (Anderson 2016:306) and it always used the philosophical notion that spiritual forces governed the political sphere, implying that prayer could change the political scene and sphere and institute conservative reform(Freston 2001:168). African Pentecostalism is a conservative movement, illustrated by most Christians representing nearly all denominations reading and interpreting the Bible in a conservative, biblicistic and literalist fashion. African Pentecostalism's conservatism is also demonstrated in the clothing preferred by neoPentecostalist prophets. Whilst Western believers shed formal attire for flip-flops and shorts, Africa's modern, media literate and expansionist prophets clothe themselves in expensive suits and evening wear to demonstrate the effectiveness of their brand of prosperity theology, whether proclaimed as a soft or hard brand (Bowler 2013:118).

Truth has become a problematic category in the sciences. Enlightened autonomous reason does not leave room for what is not observable; the claim to truth in theology is not measurable, controllable or repeatable (Huijgen 2017:11).

It is true that many Pentecostal scholars who entered the academy were required to abandon their ethos, oral culture and emphasis on experience to adopt the modes of logic, reason and linear thought that traditionally characterised Western biblical scholarship. Those who accepted the Western enlightenment model, in an attempt to make Pentecostalism theologically respectable, forsook their Pentecostal tradition entirely and remained in the Pentecostal church. However, they aligned themselves with evangelical fundamentalism or a rationalistically framed reaction against 'liberalism', accepting an evangelical hermeneutic and separating their scholarly life from their spiritual life - or adopted an elitist mentality of 'enlightened' Pentecostalism, attempting to retain their connection with Pentecostalism but no longer embracing its ethos (Martin 2002:220).

By accepting a version of fundamentalist, pre-millenialist dispensationalism, many Pentecostals' hermeneutic cannot account for its continuationism (Nel 2018:61; Sheppard 1984:11). ${ }^{7}$

Pentecostals found, in the words of Wheelock (1983:334), an 'arid, rationalistic, formalistic, unemotional, non-experiential and non-charismatic approach to religious life' unacceptable, representing their perception of much of Reformed spirituality (Hayford 2006:33). They derived their vitality from the African culture's emphasis on the non-conceptual aspects of life in religion and believed that the whole person should be involved in the process of religious devotion (Robeck 2006:12). The experiential component is conditional to any religious experience, which Otto (1950:3) refers to as the 'non-rational element' in religion, necessitating enthusiastic involvement as a fitting modality of religious expression (Wheelock 1983:336).

They did not practice theology in the traditional way of propositional exposition of doctrines ${ }^{8}$ but utilised sermons, hymns and spirituals, testimonies, conferences and revival campaigns as their media and means of theology. Theology began in people's prayerful response to God and the expectation that they would be a part of divine encounter as

7.In contrast, cessationists rule out any regular supernatural gifting that includes the contemporary practice of prophecy, interpretation of tongues and other charismata of powers and miracles (Keener 2016:321).

8. However, it cannot be denied that there is a widespread current movement away from propositional theology to narrational theology, from logos to mythos. Macchia (2016:59) writes that a christocentric theology is being overshadowed by a pneumatocentric theology in which the living voice of the Spirit is viewed as a higher authority than the written Word of God. The appeal is no longer in the first place to what scripture says but to the sanctified imagination of the reader as a part of faith community. 
described in the Bible and results in the giving of testimonies. ${ }^{9}$ The presupposition of worship is that in a divine encounter, the Spirit would be the facilitator and motivator and through the Spirit, Jesus is the object of worship (Alvarado 2016:222). Narrative and testimony have made Pentecostalism unique and served as legitimate and productive theological categories in and about themselves (Smith 2018:536). They served as a guiding theological engine (Payne 2018:542). The object of their theological reflection is a relationship, consisting of humans encountering God through God's Spirit, making theology a dialectical endeavour. And they participated in the event that serves as a precondition for being enabled to talk about God in an embodied way. The notion of an atheistic or agnostic theologian falls outside their frame of reference.

This does not necessarily imply that experience has become their norm in theologising endeavours. ${ }^{10}$ What it does imply is that they granted epistemological priority to the Spirit in a prayerful receptivity (Land 1993:27).

They expected to encounter the Spirit in the same way as described in the scripture because they stand in pneumatic continuity with the faith community that birthed the scriptures (Erwin 1981:22).

A result of the emphasis on and expectation of an experiential and dynamic element is that emotional reactions are an integral part of Pentecostal worship experiences. Essential to Pentecostal worship is the church's charismatic structure (a term popularised by Küng (1967) in his Die Kirche) that distinguishes Pentecostal worship through its dominance of oral rather than written communication, its preference for narrativity of theology and witness, maximum participation being granted at the levels of prayer, reflection and decisionmaking, its allowance of visions and dreams in all worships and its fostering of experiences of interaction between body and mind (Hollenweger 2005:17-18). When believers meet God they laugh and cry, dance and wait in stillness, weep in remorse or joy and respond to the preaching of the Word in an effective way. Interactive corporate worship is deeply felt, easily observable and encouraged.

One of the by-products of emotional elements standing central to Pentecostal spirituality is that emotionally unstable persons may be attracted to Pentecostal worship services, soliciting criticism of such emotional outbursts that may deface their spirituality. In several cases, the risk Pentecostal worship leaders took by allowing such person to contribute to the worship service benefited the individual who eventually received inner healing.

9.Barth (1949) calls prayer the first and basic act of theological work that facilitates an encounter with the object of theological reflection, which consists of a 'Thou'. It implies that theological work should be a form of liturgical and dialogical act. Certainty in our knowledge of God lies not in formulated doctrines but in acknowledging, invoking and petitioning the God who makes the divine Word accessible to human beings (Barth 1949:17-19).

10.Pentecostal experience is defined as the community's mode of being, doing and living (Campos 1989:1), as a means of understanding that moves from experience to testimony to doctrine to theology and back again, implying that it is more oral than written, more affectively rational than principles - rational and more narrative than strictly propositional.

\section{African Pentecostal spirituality as part of mystical tradition}

It is argued that African Pentecostalism can best be understood, not in Western academic theological categories, but as a modern instantiation of the mystical stream of Christianity recognisable throughout history that exemplifies something intrinsic to the manner of being a Christian, as argued convincingly by Castelo (2017) and others. ${ }^{11}$ This author does not think that most African Pentecostals would be happy to hear that their spirituality is linked to the mystical tradition; in some instances, they would probably not understand a term that is not heard that much in Western theological endeavours. Some might object to the mystical link because they might see something pagan or superstitious in it. Seen in the light of the above argument, Pentecostals have to reject divisions used widely in Protestant circles between theology and spirituality. In their practice, they already work to ensure a genuine interface between the two. In their experience, God-knowledge is not generated exclusively by actions of the intellect but in the crucible of encounters between God and believers, where the open Bible signifies the menu of expectations of what God can still do whilst providing the language to describe their experiences and its diversity. Through the biblical text, God creates in our imaginations an alternative image of reality, a new vision of how the world could be and the Pentecostal worshiping communities' lived experience becomes a gauge for testing the narratives of biblical text (Ellington 2001:257). The present author argues that what African Pentecostal spirituality requires to describe their unique way of doing theology/ spirituality would be enriched by learning the language of mysticism in an ebb and flow of the two traditions in dialogue, although it does not imply a wholesale emulation of mystical tradition. It can contribute towards a fuller and more nuanced understanding of God-knowledge for them if it is carried out within Pentecostalism's own context and theology, which couldn't be provided by Western theological categories (Castelo 2017:77).

To start with, it is imperative to define critically the term 'mysticism' as it relates to Pentecostalism's own theological tradition. It is assumed that mystical traditions have historically existed within Christianity in all periods from the start of the church until today, even if only in mutated forms. Mystical traditions and figures have largely functioned on the edges of the Western theological mainstream, in contrast to the Eastern church, where mysticism in its theology and practice played a much appreciated and influential role. The following questions could be asked: What is the relation between Christianity and the mystical tradition? Does Christianity stand at the core of a mystical faith, or are the mystical figures and movement of the past tangential and highly idiosyncratic representations of a religion that consists of something else?

11.Alfaro (2018:548) calls Castelo's (2017) book a primer for anyone interested in understanding the mystical orientation of Pentecostal faith and thought. Other Pentecostals who argue in the same vein are Palmer (1988), Land (1993), Pinnock (1996), Cross (2000) and Jacobsen (2003). 
The present author contends that much of the language, events and practices of the Christians of the first three centuries have to be understood as inherently and thoroughly mystical and that these practices were based on philosophical ideas of a dualist world in neo-Platonist terms, of a visible world where events are determined by what happens in the invisible world, where good and evil, and God and Satan clash regularly. The fortunes in different invisible battles of spiritual realm are reflected in the political, economic and social events that arrange people's daily lives. As some examples of such mystical language and practices in the New Testament, Castelo (2017:58) refers to Jesus' farewell discourses as recounted in the Gospel of John, the Day of Pentecost with its outpouring of the Spirit and accompanying signs, the guidance of the Spirit depicted in the book of Acts, the role the Spirit played in the equipment of believers for service in spreading the news of the gospel of Jesus Christ and the categorisation of charismata in 1 Corinthians 12, 14; Romans 12:6-8; Ephesians 4:9-16 and 1 Peter 4:11. It is possible (and necessary) to describe the formulation of the early church's doctrines such as the communion meal, baptism, Christology, trinitarianism and incarnation in terms of their mystical dimensions and qualities, as readily demonstrated by Louth (1981:xi).

Especially, the Western church lost its appreciation of mystical dimensions after the Constantinian marriage between church and state, a stereotyped historical perspective held by many Pentecostals since the days of their inception. Pentecostalism then represents a particular and successful kind of resurgence, although not the first or the only one, of the early and later mythical dimensions of Christianity within a larger Western context. It provides the opportunity for the west to be able to account for things that are inconsistent with the tenets of its preferred epistemology, especially as challenged by postmodernity. In reminding the Western church of long-standing features of mystical Christianity, Pentecostalism can (and has already acted to an amazing degree) equip the Protestant church to reach post-modern human beings more effectively by using the language and idiom of post-modern people in terms of their value systems and worldview.

It is submitted that Pentecostalism is expressly focused to reach the needs of the effective core of human beings, and this is what makes it a mystical tradition (Smith 2010:77). Several Pentecostal scholars have reached the same conclusion (such as Albrecht 1999:238-240; Chan 2000; Coulter 2001; Poloma 2003).

Another prominent author who propagates Pentecostalism as a mystical tradition is Cox (1995), an outsider from Harvard Divinity School who presents a sympathetic reading of Pentecostal sentiments. The author of The secular city, Cox (1965) wrote in the 1960s that religion was in the process of being engulfed by secularism. He further wrote in the 1990s that the upsurge in religiosity, particularly of the Christian charismatic variety, had caught him by surprise. He argues that the reason for the popularity of Pentecostalism and the accompanying Pentecostalisation process in mainline churches, apart from its connections in Africa with the traditional African worldview and ATRs, is its attention to the religious affections. Cox $(1995: 10,14)$ calls Pentecostalism as the most experiential branch of Christianity. Its emphasis on the experiential resulted in a more holistic way of ministry where the cerebral is subordinated by the effective; Spirit baptism is experienced as a transformation of every aspect of being human, including the value system, volitional decision-making, worldview and attitudes towards suffering and persecution. In the words of an early pioneer, David Wesley Myland, when the Spirit entered one's life, it was like swallowing 'God liquidized', changing one's life to the core (Jacobsen 2003:2). Whilst some Protestant churches seemingly end the spiritual journey in the acceptance of creed as demonstrated in ceremony and ritual, Pentecostals are always looking for new encounters with God that would enlighten their present situation in terms of God's will for their lives. They interpret their daily lives in terms of magical realism, implying an enchanted worldview with struggles in the invisible world between good and evil reflected in what happens in the lives of people, as a significant element of primal spirituality that refers to the largely unprocessed nucleus of the psyche in which the unending struggle for a sense of purpose and significance goes on (Cox 1995:81). In this way, it helps people to recover an elemental spirituality that consists of primal speech (consisting of glossolalia, ecstatic utterance and the language of the heart), primal piety (consisting of mystical experiences, trances, dreams and other archetypal religious expressions) and primal hope (which consists of an expectation of a better future). The focus on primality coincides with a deeply embedded human religiousness, a primal spirituality, that works from the universal deep sense that we are homo religious (Cox 1995:82-83).

Cox (1995:100-101) diagnoses an ecstasy deficit in contemporary secular Western societies as the result of human beings shielding themselves from their deeper registers and resisting lowering their perceptual barriers that originated in the distinction between cognitive and emotional sides of life, between rationality and symbol and between the conscious and unconscious strata of mind. Pentecostalism intuitively reacts to this deficit. Its tongue-speaking, for instance, taps into a deep substratum of human religiosity as a radical departure from evangelical Protestantism. By using the jargon found in the Bible, Pentecostals explain their intense, immediate, interior and embodied way of doing religion in clear theological categories, based on their personal experience of encounters with God (Cox 1995:87, 91). In this way, they carry mystical terms into their Lebensraum, attempting to define their spiritual experiences with terms that defy their purposes because of the mystery at the heart of their experience, which is God. Their inability to define God in clear theological categories has to do with the illiterateness and semi-literateness of many Pentecostals but also their precondition that God should first be encountered before any theological endeavour is possible. It also explains 
their anti-intellectualist urge to ensure that their religion does not become what they perceive as the lifeless form-driven liturgy and preaching characteristic of a part of Protestantism and that Protestantism justified by a cessasionist position that for practical reasons denies any divine or miraculous involvement in the daily lives of believers.

Mysticism should be defined critically to ensure that the debate does not bog down in generalities. Louth's (1981:xv) characterisation of mysticism as a search for and experience of immediacy with God is used.

Mystics are not content to gather information about God, whether through personal and collective Bible studies or theological endeavours; nothing satisfies them except the encounter with God that leads to a union with God. God, the ultimate, is searched for, not for its own sake but because God is the soul's ultimate longing. This forms the heart of mysticism, in that immediacy is sought with the object of pursuit.

Significantly, Louth (1981) does not elaborate more on the object, implying an amorphous end or goal that reflects the conviction that the encounter is exclusively the initiative of the heavenly one and its results are inexplicable within the limitations presented by human language and logic. Tonguespeaking and other ecstatic utterances demonstrate this inability and transcend human puny capacity to describe it (Cox 1995:95-96). In this way, Cox's main focus is not on Pentecostalism as such but rather on this amorphous category of primal spirituality that is exemplified by Pentecostalism (Wariboko 2011:403, 2014:64).

Castelo (2017:65) argues that Pentecostals cannot use the language of mysticism as religious scholars typically do because they operate from different ' confessional' standpoints. They cannot accept that all religious traditions are speaking of the same thing, a mysticus intuitus as part of the human condition of homo religious, despite their doctrinal differences. Pentecostals can also not share the theological agnosticism required of religious scholars; on the contrary, their ethos of direct and subjectivist involvement with the object of their study form the core of their identity. They focus their attention and passions on who God is and what God is doing, and they identify 'God' as the one revealed in the incarnation of the Christ through the power of the Spirit. At the same time, they accept the Spirit's activity and presence in all of creation, penetrating all aspects of the created order (York \& York 2006:219). They can apply the term mysticism only in an emic (insider) way; they do not dissect spirituality in terms of its phenomena but live and practice it in an involved and embodied manner.

Religious scholars are also not united in defining mysticism and it is highly contested in religious discourse.

Mostly Protestant textbooks on systematic theology begin with a discussion of the revelation of God, mainly found in the Bible, with an underlying scepticism about 'mystery', whilst their Eastern Orthodox counterparts start with 'mystery' as an essential element of revelation. Mystery can on the one hand be understood as a puzzle that needs to be solved; its primary characteristic is what is unknown and that needs to be unravelled or explained away. There is a second way of interpreting mystery. For Pentecostals, a theological account of mystery is concerned with God, the unknowable mystery. God is a revelational mystery in that God can only be known insofar as God reveals Godself in different contexts. God is self-disclosing, and the disclosure shows one who falls outside any human frame of reference and defies categorisation and definition. The distinction is significant: one does not approach the mystery of God with the goal to explain the mystery away but approaches God on the basis of existing knowledge based on historical experiences of God with people over time and in new encounters with God that lead to richer dimensions of the mystery that cannot be categorised or defined (Boyer \& Hall 2012:6). It implies that theology cannot be effectively divorced from spirituality without cutting its roots.

Revelational mystery requires an object-specific rationality and methodology because its frameworks and terms are determined by its 'object of investigation' (Castelo 2017:68). The mystery is knowable because it was revealed repeatedly in the past, and is revealed continuously in the present, through self-presentation of the divine. In engaging with the mystery, one is overwhelmed by awe, wonder, amazement and surprise; the mystery invades one's life and transforms it positively and holistically. Whilst the revealed mystery is understood by way of rational exploration, it represents a deeper and more complex substantiality than reason is familiar with (Boyer \& Hall 2012:11). For this reason, the mystery remains essentially impenetrable and unknowable even after it is revealed. Its depth or density transcends human rational and effective capacities. To speak of God, one requires the category and language of mystery, which implies that as human creatures we struggle to find the concepts and phrases necessary to say anything about the Creator.

One's personal biases, contextualising conditions and other limits restrict one in speaking and thinking of what ultimately is beyond us (Wirzba 2013). Because God created everything ex nihilo, God is transcendent and totally different, terms that Christians use to hide their embarrassment when they attempt to speak about the rich mystery that God represents.

The implication is that God-knowledge is not achieved by anything human beings do, but it is rather a kind of participation in grace, leading to devotion and attentiveness to God who reveals Godself. To know God is dependent on God's activity of revelation, one cannot know God but only obtain information about God from others' ideas and experiences and one's own encounter with God. Godknowledge is dependent on relational and interpersonal dynamics (Louth 1978:2). This implies that one encounters and is encountered by God as a precondition for Godknowledge, suggesting that realism is at work. As long as God is a projection of one's desires or a form of wishfulfilment, God cannot be a self-subsistent other and the 
ground of being that everything created is dependent on God. How can one then talk of knowing God and talking about God? It is much easier to analyse other people's views about God or the idea of God than to ask: Who is this God for me? (Louth 1978:1-3), because academic theology is saddled with inability to know and describe its subject matter with confidence (Castelo 2017:73), suggesting that humility and gratitude are necessary virtues in all theological endeavours. Mystical theology provides the concepts of non-knowing to understand the object of theology's knowing (Krüger 2018:xx). In mysticism, our rational, fact-based words eventually dissolve, but from there we may eventually resume talking, yet conscious of the radical relativity of all such talk (Krüger 2018:xix).

Encounter is thus a condition for apprehending the mystery, and spirituality denotes the practices and activities that serve such an encounter as purpose and goal. The experience of mystery cannot be evoked by free will; it is a gift at the discretion of the other subject. It can, however, be prepared for in openness and waiting in silence for God to reveal Godself as God wills (Louth 1978:3). For this reason, the language of epiclesis within the liturgical life of the church suggests best the doxological modality needed for Pentecostal theology (Castelo 2017:73). Spirituality is the personal growth that occurs as a result of what happens when the faith community meets before God, and that's why spirituality is communal and mutual, oriented towards the God who makes Godself known within the pattern of life known as the church, which is an establishment of God (McIntosh 1998:6-7).

A part of contemporary theology experiences an epistemological crisis that hinders it to speak effectively or persuasively about God and God's present involvement in the world, partly as the result of a shift from a Ptolemaic to a Copernican worldview and the privileging of reason and empiricism that led to the questioning of all institutional authority, the exaltation of subjective experience at the cost of objective 'truth' and the disenchantment and secularisation that characterised Western society. Another result was the privatisation of religion, where spiritualitas before the 12th century BCE referred to the power of God animating the Christian life, it now referred to a refined state of the soul consisting of inner purity and exaltation (McIntosh 1998:7-8). In this way, theology lost its very foundation by focusing on the mechanical quest for spirituality and divorced itself from spirituality.

Pentecostalism intuitively sensed dangers in academic theology that severed the relationship between theology and spirituality, as demonstrated by their restorationist and primitivist urge. ${ }^{12}$ Academic theology does not succeed in

12. With 'primitivism' is meant any effort to deny history, or to deny the contingencies of historical existence, by returning to the time before time, to the golden age that of historical existence, by returning to the time before time, to the golden age that preceded the corruptions of life in history (Wacker 1984:197). According to Wacke (1984:198-199), early Pentecostals manifested three patterns of primitivism: (1) philosophical primitivism with their belief that they could know absolute truth in very personal manner which was unencumbered by the limitations of finite existence existed at a preconceptual level of their worldview; (2) historica primitivism that consists of the notion that they replicated New Testamen Christianity, which explains why they found church history irrelevant; and (3) ethical primitivism, a cluster of anti-modernist behaviour patterns which were accounting for the identity and faith-culture of Pentecostals even though some Pentecostal scholars attempted such accounts of their ethos. In their call for the restoration of 'New Testament Christianity' and 'old-time religion', Pentecostals realised the importance that theology and spirituality should be reconnected so that they can mutually inform and constitute one another (Castelo 2017:93). Only such a successful reconnection would ensure that Pentecostal theology reflects and meditates on the experience of God's presence that leads to the epistemological certainty of the immanence of God (Smith 2010:50).

At the same time, the divide between theology and spirituality should be lively and interactive, in contrast to most of Western academic theological traditions. Some scholars have noted that Pentecostals fit better with a pre-modern (or better, para-modern) worldview, as do the people of Africa. On many counts, they are out of step with several currents of Western theology (Castelo 2017:94). For instance, they see 'neutrality' in the interpretation of the Bible as an illusion, a commitment of the enlightenment project. Their hermeneutic that involves one's present situation in the process of interpreting the Bible underlines the role of one's theological commitments in the process of interpretation.

In mystical theology, spirituality and theology mutually inform and constitute each other. It is suggested that African Pentecostals can benefit in several ways by learning from this ancient tradition. In the first place, if the inference is correct that Pentecostalism is related to Christian mysticism, it implies that Pentecostalism is not a new phenomenon in the church but that their speech, practices and convictions fall within an age-old tradition that has become marginalised by modernist anti-supernaturalist, de-supernaturalised and cessationist theological tendencies (Keener 2016:91). ${ }^{13}$ Pentecostal belief in miracles, exorcism, interference of evil spirits and active work of the Spirit follows in a long tradition that goes back to the early church and the Old Testament. In the past, some Pentecostals were marginalised and discriminated against for their spiritual practices and in some cases in Africa it may still be happening. However, they may find confidence in their link with an ancient and venerable tradition, especially in the Eastern church.

Secondly, when Pentecostals see the link with mysticism and acknowledge their indebtedness to this tradition, they find the language of mystical theology helpful in finding the necessary concepts and phrases to state the unsayable that their mystical experiences represent. There are many publications of mystical fathers and mothers that are widely available in the light of recent interest in the subject and the Philokalia as an anthology of such writings is a good place to

patterned after the New Testament in order to bring about the power of New Testament Christianity.

13.See, for example, the remark of Martin (2017:137) that research (in his case, 3.See, for example, the remark of Martin (2017:137) that research (in his case,
sociological research) had to conform to the criteria of modernity, and prominent among these criteria was the rejection of supernaturalism whilst its object of among these criteria was the rejection of supernaturalism whilst its object of
study, in his case Pentecostalism, is defined by its being exuberantly religious, supernatural and subjective. 
start. ${ }^{14}$ The recurrent concepts and categories found in mystical theology are particularly suitable to define Pentecostals' unique contribution to theology and express their self-identity.

Lastly, mysticism is characterised and defined by certain customs or disciplines found in both Western and Eastern Christian traditions and it is suggested that Pentecostals can benefit by taking notice of it. The wide use of the works of Foster $(1978,1981,1985)$ amongst Pentecostals suggest that the practice of disciplines is already a part of many individual Pentecostals' spiritual development. Well-attested practices such as lectio divina, the Stations of the Cross, contemplation and meditation can further enrich Pentecostal spirituality.

A last question to be asked is, in what ways can the categories and concepts of mysticism benefit and enrich Pentecostals in defining and expressing their self-identity and spirituality? Several aspects of their spirituality are aligned with mystical practices and only a few would be mentioned. Although these aspects may not sound distinct for Pentecostals because they are commonplace and mundane in their spirituality, for outsiders it may not be so obvious. The first aspect is their emphasis on holiness, a legacy of its link with the 19th-century holiness tradition that promoted universally accessible and life-transforming religious experiences for all believers with the accompanying experience of power and purity. The Holy Spirit sanctifies the believer in and through the watershed experience of Spirit baptism, an event that Pentecostals believe is repeated in their lives through the practice of the charismata with which individuals are endowed. Whilst justification addresses sin in the life of individual, sanctification is the gift of the power of Spirit baptism with the specific aim to equip the believer for the ministry of the gospel to others (Jacobsen 2003:70). Sanctification as the work of the Spirit combines it with the equipment of power for effective ministry through the charismata, or individuations, manifestations or embodiments of grace (Käsemann 1994:334). A prerequisite for the equipment with power is periods of consecration and purgation for the power to take hold of individual in a fitting way.

Another aspect of Pentecostal spirituality that demonstrates its mystical character is found in the different way of interpreting and participating in reality, based on an experience with God that exudes a 'magical realism' that surpasses mere cognitive reasoning (Cox 1995:71). They view the world as a God-drenched reality, as the result of their collective spirituality that comprises miracles, tongues

14.The Philokalia is a collection of texts written between the 4th and 15 th centuries by proponents of the mystical Orthodox Christian tradition. It was first published in Greek in 1782, translated into Slavonic and Russian and later a selection of texts from the Philokalia was made available in English before a full translation started appearing in 1979 (eds. Ware, Palmer \& Sherrard 1979-1995). The ancient concepts and practices were translated into the modern idiom of the 20th century by several proponents, of which Thomas Merton, Thomas Keating. Evelyn Underhill by several proponents, of which Thomas Merton, Thomas Keating, Evelyn Underhil and Basil Pennington were some of the most prominent ones. The 4th-century Gregory of Nyssa's Life of Moses and Athanasius' The Life of Antony, the 16thcentury Saint John of the Cross' Dark Night of the Soul, the 17th-century Madame Gest Best Rule of a Holy Life and other works were influential in the mystical tradition being accepted and practised by many churches and Christian believers in the $21 \mathrm{st}$ century. speaking, prophecy, prayer, laying on of hands, ecstatic speaking with anointing, praising God through music, sharing of testimonies, responsive preaching, tarrying at the altar, praying through and more. ${ }^{15}$ These kinds of incidents in their communal worship shape and transform their ethos, fed by their continuous expectation of and attention to growth in their spiritual development. In this way, Pentecostal spirituality facilitates increase of personal and collective God-knowledge. It is probably correct to state that most Pentecostal theology has been carried out in the context of prayer and worship (Hunter 2013:3) because Pentecostals purpose to worship in harmony with the ways of the Spirit and the Spirit urges them from the start to exalt Jesus as Lord (Martin 2017:160). Their theology is Christocentric because of their pneumatological grounding of it.

Pentecostalism's practice of ecstatic speech also demonstrates its mystical character. When speaking in tongues, Pentecostals affirm that their 'spirit' participates in the presence and work of the Spirit and tongues provide appropriate language to speak about and with the unsayable mystery. Their prophecy is ascribed to insights that they assign to the Spirit, as is the case with the interpretation of tongues. In speaking about these phenomena, they may find the concepts useful that were developed by mystical theologians.

Their attention to human affections in the way the worship service is arranged is another factor that demonstrates their mystical tendencies. Without eliminating the contribution of intellect, Pentecostals create room for people to express their encounter with God in a democratic and individual manner through embodied actions and the accompanying expression of affections.

Lastly, Pentecostalism's persistent emphasis on 'encounter' is a primary factor in its being a mystical tradition. Warrington (2008:20) explains that its essence is the evident need for a personal, experiential encounter with the Spirit of God who reveals Christ in power and glory. Pentecostals expect and believe that they encounter God in life-changing ways in their adoration and worship. They delineate the integral elements of the theology of worship as rapture, that is the quality of ecstasy that is inherent to Pentecostal worship, rapport, comprising the union of love that evolves between the worshiper and God, and between all those who worship God and proleptic, as a spiritual return to the historic events of redemption and an anticipation in which the believer is transported via the Spirit in the final glory of the kingdom of God (Alexander 2016:209). Even without referring to 'transcendence' and 'mystery', their emphasis on the manifestation of the manifest power and presence of God explains the availability of experiential God-knowledge as defined by mystical theology. Encountering God is the epistemological grounding for Pentecostal theological methodology, where sensing, feeling and experiencing God

15.The similarities in Pentecostals' unique interpretation of reality are demonstrated in their testimonies as part of their strong oral tradition (Anderson 2014:244) that has always been an essential part of their worship services and are characterised has always been an essential part of their worship services and are characterised
by its use of biblical language to describe and interpret the experiences and its by its use of biblical language
mystical view of the world. 
constitute the orienting epistemic framework for Pentecostal theology (Castelo 2017:81, 99). Encounter implies for them an implicit theological realism with worship defined as the space where people encounter and are encountered by God.

Worship services are characterised by the expectation that God 'would turn up' and overwhelm people by power that would heal, deliver, provide and surprise in an event that would overwhelm participants' creaturehood. A sign of this encounter would be that people would cry, shake, scream or be slain by the Spirit because their bodies are overwhelmed by the touch and power of the living God, representing a sense of the divine that is also typical to 'mystical theology'.

\section{Conclusion}

The article submits that academic theology is not successful in accounting for the identity and faith-culture of African Pentecostals because they historically emphasised on a holistic effective spirituality that links with certain aspects of ATR and worldview. What African Pentecostals need for clarifying their identity and explaining their spirituality is another mode and it is proposed that the language of mysticism is the suitable mode. The implication is that Pentecostalism could be identified as a mystical tradition in line with an ancient tradition of Catholic church. For mysticism, it is essential that theology and spirituality mutually inform and constitute each other, serving as a requirement for Pentecostals to ensure that their experiences of encounter with God lead to the epistemological certainty of immanent God.

Pentecostals implicitly and intuitively operate out of mystical sensibilities in an ethos where worship reflects their thirst for an encounter with God that transforms their lives. Experiencebased encounters with God are valued above encyclopaedic knowledge of God because of its potential to transform individual (Warrington 2008:26).

African Pentecostals can benefit by learning from this ancient tradition in several ways: by realising that their connection to Christian mysticism implies that their spirituality is not a new phenomenon, by utilising concepts of mystical theology to help find the words necessary to state the unsayable that their mystical experiences represent and by utilising the practice of disciplines developed over centuries in Western and Eastern Christian traditions.

The article closes by asking in what ways mysticism could benefit Pentecostals in defining and expressing their selfidentity and spirituality. In Pentecostal spirituality, the separate experience of sanctification, a different way of interpreting and participating in reality, their emphasis of affections in religious expression, ecstatic speech and their continuous emphasis on a personal, experiential encounter with the Spirit of God are some aspects that define their spirituality and demonstrate their relation with mystical theology, necessitating concepts developed in mystical theology through the ages.

\section{Acknowledgements}

The author thanks the National Research Foundation of South Africa (NRF) for providing funding for this study. The views expressed do not necessarily reflect the view of the NRF.

\section{Competing interests}

The author has declared that no competing interests exist.

\section{Author's contributions}

I declare that I am the sole author of this research article.

\section{Ethical consideration}

This article followed all ethical standards for a research without direct contact with human or animal subjects.

\section{Funding information}

This research received no specific grant from any funding agency in the public, commercial or not-for-profit sectors.

\section{Data availability statement}

Data sharing is not applicable to this article as no new data were created or analysed in this study.

\section{Disclaimer}

The views and opinions expressed in this article are those of the author and do not necessarily reflect the official policy or position of any affiliated agency of the author.

\section{References}

Albrecht, D., 1999, Rites in the spirit: A ritual approach to Pentecostal/charismatic spirituality (Journal of Pentecostal Theology Supplement 17), Sheffield Academic Press, Sheffield.

Alexander, K.E., 2016, “'Singing heavenly music”: R. Hollis Gause's theology of worship and Pentecostal experience', in L.R. Martin (ed.), Toward a Pentecostal theology of worship, pp. 201-220, CPT, Cleveland, TN.

Alfaro, S., 2018, 'Review of Castelo's Pentecostalism as a Christian mystic tradition', Pneuma 40(4), 546-554.

Alvarado, J.E., 2016, 'Pentecostal worship and the creation of meaning', in L.R. Martin (ed.), Toward a Pentecostal theology of worship, pp. 221-234, CPT, Cleveland, TN.

Anderson, A.H., 1991, Moya: The Holy Spirit in an African context (Manualia didactica 13), Sigma, Pretoria.

Anderson, A.H., 2014, An introduction to Pentecostalism, 2nd edn., Cambridge University Press, Cambridge.

Anderson, A.H., 2016, 'The Spirit and the African spiritual world', in V. Synan, A. Yong \& J.K. Asamoah-Gyadu (eds.), Global renewal Christianity: Africa, vol. 3, pp. 304-320, Charisma House, Lake Mary, FL.

Asamoah-Gyadu, J.K., 2005, African charismatics: Current developments within independent indigenous Pentecostalism in Ghana, Brill, Leiden.

Barth, K., 1949, Prayer, transl. S. Terrien, Holt, Rinehart and Winston, New York, NY.

Bowler, K., 2013, Blessed: A history of the American prosperity gospel, Oxford University Press, Oxford.

Boyer, S.D. \& Hall, C.A., 2012, The mystery of God: Theology for knowing the unknowable, Baker Academic, Grand Rapids, MI.

Campos, B.I., 1989, 'From experience to Pentecostal theology', paper presented at the encuentro pentecostal latinoamericano, Buenos Aires, Argentina, Tr. by J. Beaty \& S.J. Land, 3-5th June, 1988.

Castelo, D., 2017, Pentecostalism as a Christian mythical tradition, Eerdmans, Grand Rapids, MI.

Castelo, D., 2018, 'Response to critics', Pneuma 40(4), 554-561. 
Chan, S., 2000, Pentecostal theology and the Christian spiritual tradition (Journal of Pentecostal Theology Supplement 21), Sheffield Academic Press, Sheffield.

Coulter, D., 2001, 'What meaneth this? Pentecostals and theological inquiry', Journal of Pentecostal Theology 10(1), 38-64. https://doi.org/10.1177/096673690101000103

Cox, H., 1965, The secular city: Secularization and urbanization in theological perspective, Macmillan, New York, NY.

Cox, H., 1995, Fire from heaven: The rise of Pentecostal spirituality and the reshaping of religion in the twenty-first century, Da Capo, Cambridge, MA.

Cross, T.L., 2000, 'The rich feast of theology: Can Pentecostals bring the main course or only the relish?', Journal of Pentecostal Theology 8(16), 27-47. https://doi. org/10.1177/096673690000801602

Dierks, F.A.J., 1983, 'Communication and world-view', Missionalia 11(1), 43-56.

Ellington, S.A., 2001, 'History, story, and testimony: Locating truth in a Pentecostal hermeneutic',Pneuma21(2),245-263. https://doi.org/10.1163/157007401X00195

Erwin, H.M., 1981, 'Hermeneutics: A Pentecostal option', Pneuma 3(2), 11-25. https://doi.org/10.1163/157007481X00098

Foster, R.J., 1978, Celebration of discipline, Harper \& Row, New York, NY.

Foster, R.J., 1981, Freedom of simplicity, Harper Collins, New York, NY.

Foster, R.J., 1985, Money, sex \& power, Harper \& Row, New York, NY.

Freston, P., 2001, Evangelicals and politics in Asia, Africa and Latin America, Cambridge University Press, Cambridge.

Harris, A.L., 2016, 'An African American contribution to the theology of worship: Considering three situations of integrated African American led worship from precivil rights times', in L.R. Martin (ed.), Toward a Pentecostal theology of worship, pp. 246-264, CPT, Cleveland, TN.

Hayford, J., 2006, The charismatic century: The enduring impact of the Azusa street revival, Hachette Book, New York, NY.

Hollenweger, W.J., 2005, Pentecostalism, Baker Academic, Grand Rapids, MI.

Huijgen, A., 2017, Drievoudig bewogen: De innerlijke samehang van triniteit en Oude Testament, Theologische Universiteit Apeldoorn, Apeldoorn.

Hunter, H.D., 2013, 'Introduction: Global Pentecostals are not "Protestant" and are not "western"', in H.D. Hunter \& N. Ormerod (eds.), The many faces of global Pentecostalism, pp. 1-5, CPT, Cleveland, TN.

Jacobsen, D., 2003, Thinking in the Spirit, Indiana University Press, Bloomington, IN.

Johnson, T.M., Barrett, D.B. \& Crossing, P.F., 2010, 'Christianity 2010: A view from the New Atlas of Global Christianity', International Bulletin of Missionary Research 34(1), 36. https://doi.org/10.1177/239693931003400109

Käsemann, E., 1994, Commentary on Romans, Eerdmans, Grand Rapids, MI.

Keener, C.S., 2016, Spirit hermeneutics: Reading scripture in light of Pentecost, Eerdmans, Grand Rapids, MI.

Krüger, J.S., 2018, Signposts to silence. Metaphysical mysticism: Theoretical map and historical pilgrimages, Theological and Religious Studies, HTS Religion \& Society Series 2, AOSIS, Cape Town. https://doi.org/10.4102/aosis.2018.BK52.00

Küng, H., 1967, Die Kirche, Piper, Munich.

Land, S.J., 1993, Pentecostal spirituality: A passion for the kingdom, Cherohala, Cleveland, $\mathrm{OH}$.

Louth, A., 1978, Theology and spirituality, SLG, Oxford.

Louth, A., 1981, The origins of the Christian mystical tradition: From Plato to Denys, Clarendon, Oxford

Macchia, F.D., 2016, 'Signs of grace: Towards a charismatic theology of worship', in L.R. Martin (ed.), Toward a Pentecostal theology of worship, pp. 153-164, CPT, Cleveland, TN.
Martin, D., 2002, Pentecostalism: The world their parish, Blackwell, Oxford.

Martin, D., 2017, Secularisation, Pentecostalism and violence: Receptions, rediscoveries and rebuttals in the sociology of religion, Routledge, London.

McIntosh, M.A., 1998, Mystical theology, Blackwell, Malden, MA.

Nel, M., 2018, An African Pentecostal hermeneutics: A distinctive contribution to hermeneutics, Wipf \& Stock, Eugene, OR.

Omenyo, C.N., 2014, 'African Pentecostalism', in C.M. Robeck \& A. Yong (eds.), The Cambridge companion to Pentecostalism, pp. 132-151, Cambridge University Press, New York, NY.

Otto, R, 1950, The idea of the holy: An inquiry into the non-rational factor in the idea of the divine and its relation to the rational, 2nd edn., Oxford University Press, of the divin
London.

Palmer, P., 1988, Selected writings, Paulist, New York, NY.

Payne, L., 2018, 'Review of Castelo's Pentecostalism as a Christian mystic tradition', Pneuma 40(4), 540-546.

Pinnock, C.H., 1996, Flame of love: A theology of the Holy Spirit, InterVarsity, Downers Grove, IL.

Poloma, M.M., 2003, Main street mystics: The Toronto blessing and reviving Pentecostalism, Altamira, Lanham, MD.

Quayesi-Amakye, J., 2016, “Nativizing" the gospel: Pentecostalism and theology in Africa', in V. Synan, A. Yong \& J.K. Asamoah-Gyadu (eds.), Global renewal Christianity: Africa, vol. 3, pp. 287-303, Charisma House, Lake Mary, FL.

Robeck, C.M., 2006, The Azusa street mission and revival: The birth of the global Pentecostal movement, Nelson, Nashville, TN.

Sheppard, G.T., 1984, 'Pentecostals and the hermeneutics of dispensationalism: The anatomy of an uneasy relationship', Pneuma 6(2), 5-33.

Smith, J.K.A., 2010, Thinking in tongues, Eerdmans, Grand Rapids, MI.

Smith, K., 2018, 'Review of Castelo's Pentecostalism as a Christian mystic tradition', Pneuma 40(4), 535-540.

Taylor, J.V., 1963, The primal vision: Christian presence amid African religion, SCM, London.

Wacker, G., 1984, 'The functions of faith in primitive Pentecostalism', Harvard Theological Review 77, 353-375. https://doi.org/10.1017/S0017816000027280

Ware, F.L., 2005, 'The use of signs in the preaching of Charles Harrison Mason', Paper delivered at the 34th Meeting of the Society for Pentecostal Studies, 10-12 March, Virginia Beach, VA, viewed 16 January 2020, from https://www. umbrasearch.org/catalog/fc801b108762ac9848c387a0c769b85cb17b12a5.

Ware, K., Palmer, G.E.H. \& Sherrard, P. (eds.), 1979-1995, Philokalia, 4 vols, Faber and Faber, London.

Wariboko, N., 2011, 'Fire from heaven: Pentecostals in the secular city', Pneuma 33(3), 391-408. https://doi.org/10.1163/157007411X592701

Wariboko, N., 2014, The charismatic city and the public resurgence of religion: $A$ Pentecostal social ethics of cosmopolitan urban life, Charis, New York, NY.

Warrington, K., 2008, Pentecostal theology: A theology of encounter, T\&T Clark, London.

Wheelock, D.R., 1983, 'Spirit-baptism in American Pentecostal thought', PhD dissertation, Faculty of Theology, Emory University, Atlanta, GA.

Wirzba, N., 2013, 'The art of creaturely life: A question of human propriety', Pro Ecclesia 22(1), 7-28. https://doi.org/10.1177/106385121302200101

York, D.G. \& York, A., 2006, 'The Spirit in evidence: Stories of how decisions are made', in M. Welker (ed.), The work of the Spirit: Pneumatology and Pentecostalism, pp. 205-220, Eerdmans, Grand Rapids, MI. 